\title{
Microinclusions in diamonds from deposits of different genetic kimberlite types
}

\author{
KriulinaG.Yu., Garanin V.K., Vasiliev E.A., Zedgenizov D.A., Bobrov A.V., Vasiliev R.V, \\ Vyatkin S.V. \\ ${ }^{I}$ M.V. Lomonosov Moscow State University, Moscow, Russia; ${ }^{2}$ Saint-Petersburg Mining Univeristy, Saint-Petersburg, \\ Russia; ${ }^{3}$ V.S. Sobolev Institute of Geology and Mineralogy of the Russian Academy of Sciences, Russia \\ galinadiamond@gmail.com
}

Kimberlitic rocks represent the complex heterogeneous system including both mantle and crustal substrates in various proportions. Researchers of magmatic rocks widely apply and detail the different mineralogical and petrogeochemical classification schemes in dependence of the region studied. Traditionally, $\mathrm{Al}$ and $\mathrm{Mg}-\mathrm{Fe}$ mineralogical types of kimberlites are distinguished.

The analyzed petrochemical types of kimberlites included the low-titanium ( $\mathrm{TiO} 2<1 \%$, Al-type kimberlite) and mid-titanium ( $1<\mathrm{TiO} 2<2,5 \%, \mathrm{Mg}-\mathrm{Fe}$-type kimberlite) varieties. The analysis of the content of defect-structural centers in diamonds from different petrochemical types of kimberlites was performed in this study [Kriulina et al, 2011, 2012; Zedgenizov et al 2004, 2007, 2009, 2015, 2016].

Geochemical studies of syngenetic mineral and crystal/fluid inclusions in diamonds provide evidence for existence of multicomponent diamond-forming substrate in the Earth's mantle. Long-term complex studies of natural diamonds and experiments in this field allowed researchers to conclude that the mantle environment of diamond crystallization is represented by volatile-rich melts or fluids [Logvinova et al., 2008; Anand et al, 2004; Boyd, Gurney, 1986; Bulanova 1995]. In recent years, fluid and fluid-bearing inclusions have been studied in diamonds of different genesis [Izraeli et al, 2011; Klein-BenDavid et al 2004 and others].

We suggested that the presence of microinclusions was controlled by the character of crystal growth being determined by the diamond formation depth. The classic mineralogy of diamond [Orlov, 1984; Sobolev, 1978 and others] assummes that layered growth of diamond crystals is supported by high temperatures and long occurrence of crystals under the favorable conditions.

Analyzing the results of our studies and numerous published data, we can make some conclusions. The deepest crystals of octahedral and dodecahedral habit with layered and layered-zoned internal structure are characterized by chloride and chloride-carbonate inclusions of high alkalinity (SEM data), as well as by enrichment in $\mathrm{H}_{2} \mathrm{O}$ (the data of IR spectroscopy).

Octahedral diamonds with cloudy inclusions demonstrating change in mechanisms of growth and predomination of octahedral sectors at the final stage have silicate and aluminosilicate compositional trends of microinclusions (i.e. are less deep than the group of diamonds with chloride inclusions).

Crystals of cubic habit (cuboids, tetrahexahedroids, and dodecahedroids) are the most shallow, have microfibrous structure and carbonatecomposition of microinclusions in all studied pipes. These are yellow cuboids with fibrous structure and colorless or gray cube with zoned-sectorial structure.

Marginal areas of coated diamond contains both carbonate and aluminosilicate inclusions (the carbonate-silicate trend). 
Significant overlap in the carbonate-rich compositional area shows that carbonate melt is an important environment of the diamond formation in deep zones of the continental lithosphere [Bogysh et al, 2016; Zedgenizov et al 2004, 2007, 2009, 2015, 2016; Bobrov et al, 2011].

Fig. 1 shows the composition of microinclusions in diamonds from kimberlites of the different genetic types.



Fields of the composition of microinclusions in diamonds from different pipes:

Internatsional'naya, violet; Udachnaya, orange;

Komsomol'skaya, yellow; Mir, blue; Arkhangelskaya and Karpinsky, green, semitransparent; Diavik (Canada), blue; Jwaneng (Botswana), light-gray; Coffiefontain (South Africa), rose; Brazil, gray.

Fig. 1. Compositional fields of melt/fluid microinclusions in diamonds from the different deposits worldwide. The fields are shown according to the results of original studies of Russian diamonds [Bogysh et al, 2016; Zedgenizov et al 2004, 2007, 2009, 2015, 2016; Bobrov et al, 2011] and data on foreign deposits.

Diamonds from kimberlite of the Al-type are characterized by the presence of nanosized inclusions of the carbonate-silicate composition. Increase in the silicate component content indicates increase in the depth of diamond formation.

Diamonds from kimberlite of the $\mathrm{Mg}$-Fe type contain microinclusions of the chloride-carbonate composition and hydrous fluid inclusions. Since these are the deepest diamonds, mostly of the octahedral and dodecahedral habits, they are characterized by the layered growth and sometimes by thin rim overgrowing an octahedral crystal. Diamonds with layered growth mechanism contain single inclusions, almost indistinguishable because od small sizes. Among the daughter phases of microinclusions are phlogopite, biotite; IR sectra contain molecular water and $\mathrm{OH}^{-}$groups.

Continuous transitions between the parameters of the composition of water and silicate and carbonatite inclusions confirm - "melts" with increased carbonatite component are the most effective host-environment for diamonds crystallization and growth. Significant 
overlap in composition range enriched by carbonates does not permit a reliable conclusion about the specific diamondiferous deposit (field).

\section{References}

1. Anand M., Taylor L.A., Misra K.C. et al. (2004) Nature of diamonds in Yakutian eclogites: views from eclogite tomography and mineral inclusions in diamond // Lithos. 77. P. 333348.

2. Bobrov A.V., Litvin Yu.A., Dimshic A.M. (2011) Experimental studies of carbonate-silicate mantle systems in connection with the problem of diamond formation. M.:GEOS, $208 \mathrm{c}$.

3. Bogush I.N., Specius Z.V., Kovalchuk O.E., Pomazanskiy B.S. Distribution of structural impurities and fluid microinclusions in crystals of cubic habitus and coated diamond from Yubileynaya pipe (Yakutia) (2016) Geochemistry № 8. - P. 708-717.

4. Boyd F.R., Gurney J.J. (1986) Diamonds and the African lithosphere // Science. 232. P. 472-477.

5. Bulanova G.P. (1995) The formation of diamond // J. Geochem. Explor. 53. P. 1-23

6. Izraeli E.S., Harris J.W., Navon O. Fluid and mineral inclusions in cloudy diamonds from Koffiefontein, South Africa // Geochim. Cosmochim. Acta. 2004. V. 68. P. 2561-2575.

7. Kriulina, G.Yu., Garanin, V.K., Vasilyev, E.A., Kyazimov, V.O., Matveeva, O.P., and Ivannikov, P.V. (2012). New Data on the structure of diamond crystals of cubic habitus from the Lomonosov deposit. Moscow University Geological Bulletin, 67, Issue 5, 282-288.

8. Kriulina G.Yu, Garanin V.K., Rotman A.Ya, Koval'chuk O.E. (2011) Peculiarities of Diamonds from the Commercial Deposits of Russia// Moscow University Geology Bulletin, том 66, № 3, c. $171-183$

9. Klein-Ben David O., Izraeli E.S., Hauri E., Navon O. (2004) Mantle fluid evolution - a tale of one diamond // Lithos. V. 77. P. 243-253.

10.Logvinova A.M., Wirth R., Fedorova E.N., Sobolev N.V. Nanometre-sized mineral and fluid inclusions in cloudy Siberian diamonds: new insights on diamond formation // Eur. J. Mineral. 2008. V. 20. P. 317-331.

11. Orlov Y.L. (1984) Mineralogy of the diamond. Nauka, 263c.

12. Sobolev E.V. (1978) Nitrogen centers and growth of natural diamond crystals// Problems in the petrology of the earth's crust and upper mantle. Novosibirsk. C. 245-255.

13.Zedgenizov D., Rubatto D., Shatsky V., Ragozin A., Kalinina V. (2016) // Eclogitic diamonds from variable crustal protoliths in the northeastern Siberian craton: Trace elements and coupled $813 \mathrm{C}-$ $\delta 18 \mathrm{O}$ signatures in diamonds and garnet inclusions // Chemical Geology. v. 422, pp. 46-59.

14.Zedgenizov D.A., Kagi H., Shatsky V.S., Sobolev N.V. (2004) Carbonatitic melts in cuboid diamonds from Udachnayakimberlite pipe (Yakutia): evidence from vibrational spectroscopy // Mineral. Mag. V. 68 (1). P. 61-73.

15.Zedgenizov D.A., Ragozin A.L., Shatsky V.S., Araujo D., Griffin W.L., Kagi H. (2009) Mg and Fe-rich carbonate-silicate high-density fluids in cuboid diamonds from the Internationalnayakimberlite pipe )Yakutia) // Lithos, v. 112S, pp. 638-647.

16.Zedgenizov D.A., Rege S., Griffin W.L., Kagi H., Shatsky V.S. (2007) Composition of trapped fluids in cuboid fibrous diamonds from the Udachnaya kimberlite: LAM-ICPMS analysis // Chem. Geol. V. 240. P. 151-162.

17.Zedgenizov D.A., Shatsky V.S., Panin A.V., Evtushenco O.V., Ragozin A.L., Kagi H. (2015) Evidence for phase transitions in mineral inclusions in superdeep diamonds of the São Luiz deposit (Brazil) // Russian Geology and Geophysics, v. 56, pp. 296-305.

18.Zedgenizov D.A., Yefimova E.S., Logvinova A.M., Shatsky V.S., Sobolev N.V. (2001) Ferropericlase inclusions in a diamond microcrystal from the Udachnayakimberlite pipe, Yakutia // Doclady Earth Sciences, Vol. 377a, No 3, pp. 319-321. 